\title{
A Correlational Study on Teacher Educators' Assessment Literacy and Their Students' Academic Achievement
}

\author{
Sajjad Hussain* \\ Muhammad Munir Kayani ** \\ Zarina Akhtar ${ }^{* * *}$
}

\begin{abstract}
The knowledge and skills of classroom assessment is one of the requirements which have been declared in National Professional Standards for Teachers in Pakistan. Without the knowledge and skills of assessment teachers cannot effectively implement their instructional plan. This study investigated teacher educators' assessment literacy and its relationship with the academic achievement of prospective teachers. The study was quantitative correlational and survey method was adopted for data collection. Teacher educators and prospective teachers of Government Colleges of Elementary Teachers and Regional Institute for Teacher Educators were included in the population. Data were collected through an assessment literacy test from the sample groups of the study which was analyzed through mean scores, Pearson correlation and linear regression. The results illustrated that the assessment literacy of teacher educators was of average level which was significantly co-related to the academic achievement of prospective teachers. To further enhance the assessment literacy in-service trainings/workshops were recommended. Further, an Assessment Wing at federal level for the development of assessment standards at different level was also recommended.
\end{abstract}

Keywords: assessment literacy, standards, achievement, students' learning

\footnotetext{
* Lecturer, Center for Education and Staff Training, University of Swat, Pakistan, Email: sajjadhussain@uswat.edu.pk

**Associate Professor, Department of Education, International Islamic University, Islamabad, Pakistan, Email: drmunirkayani@ yahoo.com

${ }^{* * *}$ Assistant Professor, Department of Education, International Islamic University, Islamabad, Pakistan, Email: Zarina.akhtar@iiu.edu.pk
} 


\section{Introduction}

Planned teaching-learning process is the distinctive feature of formal educational institutions. For this purpose classroom activities are designed by the teachers keeping in view the institutional vision and mission. Classroom assessment is a significant feature of formal institutions which has a significant relationship with teaching learning process (Gardner, \& Gardner, 2012; Brown, 2005). It is a systematic process of data collection, analysis and interpretations aimed to reach certain educated conclusions. It is the process of making value judgments of students' learning, the effectiveness of instructional practices, classroom learning environment and the effectiveness of assessment practices itself at the classroom and institutional level (Black, Harrison, Lee, Marshall, \& Wiliam, 2004).

Originally, the assessment was deemed necessary for students' grading, certification and achievement of learning objectives. Through final term tests, interviews (viva) and performance-based assessment these results were used in educational institutions. Later with the work of William Black (1998) identified the new dimension of assessment that came into practice where assessment is used for learning (formative assessment) (Black, \& Wiliam, 2010). This approach was adopted with the assumption that assessment may also be used for improving students' learning and effective interventions in teachers' instructional practices through students' feedback. Classroom discussion, students' questioning during the instruction, one-minute tests and teacher observations are used by teachers for giving feedback to students on their learning and to adjust their instructional practices to enhance students' learning (Stiggins, 2004). Assessment for learning provides a base for immediate feedback which directly contributes to students learning, as it enables the learners to know their strengths and weakness and to correct students' mistakes in a more appropriate manner.

Similarly, soon after research studies explored another dimension of assessment that is called assessment as learning. This dimension is more students' centred where students' learning activities were designed in such a manner that through assessment tasks learning is incorporated into students (Boud, Cohen, \& Sampson, 2014). The best examples arestudents' individual and groups projects, fieldwork approach, study tours and research thesis where students' abilities and potentials are not only assessed through different yardsticks but they learn through these experiences (Nicol, \& Macfarlane-Dick, 2006). 
Likewise, for the better quality of assessment a new mechanism of three dimension assessment approach was introduced. This approach enables all the stakeholders (Students, Teachers and Peers/colleagues) to give their valuable input in the process to make it more reflective and acceptable. This approach is consisted of self-assessment, peer assessment and teachers/supervisor assessment. At self-assessment level the student personally assesses the value and worth of his/her own work (Lorna, Earl, \& Manitoba, 2006). It enables the student to critically reflect what he/she has done, where is the space for further improvement? How better he/she can do the same work? Furthermore, this mechanism also enhances students' assessment skills, creativity, critical nature and problem-solving abilities. Similarly, in peer assessment, student's work is assessed by his/her classmate where he/she is supposed to give feedback on his friends' work. Like self-assessment, peer assessment has more benefits in students' classroom learning as it supports cooperative learning among students (Scott, Alter, \& McQuillan, 2010). Furthermore, it enables the learners to study the work of their friends which is a source of their learning too. Similarly, it empowers the student to give feedback on the work of his/her friend which enhance student skills in feedback too, and it develop the reasoning skills of the students and all above it assure the students' the academic autonomy and freedom which not only motivate the student for further learning but leads him/her towards taking the responsibility of their own learning (La Paro, Pianta, \& Stuhlman, 2004).

Likewise, in supervisor/teachers' assessment, the work of students are assessed by the teacher in a standardized manner. At this level the teacher does assessment two aspects of students' learning, one-the work which was done by the student and second, their self and peer assessments. Teacher gives feedback to the students on their work as well as on the assessment they made at self and peer assessment level. All these practices significantly contribute to students' skills development such as critical thinking skills, reasoning skills, feedback and their self-confidence. Furthermore, there are marks division in self, peer and supervisor/teacher assessment which is the foundation of students' academic autonomy and freedom (Boud, Cohen, \& Sampson, 2014).

It is therefore important for teachers and other stakeholders to understand the importance of assessment and pay due attention to the knowledge and skills of assessment. Keeping in view the importance of assessment knowledge and skills, different organizations and institutions have started training, workshops and specializations in assessment studies. 
For assessment knowledge and skills, now a term is used that is assessment literacy which is the understanding of assessment knowledge, skills and inferences made on assessment data for educational decisions (Popham, 2011). Furthermore, various certificating institutions and licensing authorities such as American Federation of Teachers (AFT), National Council for Measurement Education (NCME), state department of education of United States of America, Assessment Consortiums on Assessment (Davidheiser, 2013) and National Accreditation Council of Teacher Education of Pakistan (NACTE) in the field of teaching profession have devised certain standards to ensure teachers' assessment literacy which aimed to take full benefits from the knowledge and skills in assessment of teachers for enhancing students' learning. Similarly, in Pakistan, the National Professional Standards for Teachers also identified assessment as an important standard for teachers in their professional development process. Therefore, the researchers have designed this study to investigate the assessment literacy of teacher educators and its relationship with the academic achievement of their students.

\section{Research Objectives}

This study investigated the following research objectives:

i. To analyze the current assessment literacy level of teacher educators

ii. To illustrate the academic achievement of prospective teachers

iii. To measure if the assessment literacy of teacher educators contribute into the academic achievement of prospective teachers

\section{Literature Review}

Assessment is an important element of teaching-learning process which is always the focus of researchers and experts in teacher education. There are significant research studies on assessment and its other related dimensions. Researchers have identified assessment practices as an indicator for the accountability of teaching-learning process. It enables the teachers, administrators and other stakeholders of teaching-learning process to know the extent to which the desired targets have been achieved (Davidheiser, 2013). Furthermore, from a teacher perspective, assessment helps the teachers to adjust the instructional style according to the interest and learning styles of students. Likewise, its results enable the teacher to re- plan in the instruction and made all the necessary actions which are important for improving students' learning (La Paro, Pianta, \& Stuhlman, 2004). 
A study conducted by Andersson, and Palm (2017) on the professional development program on the conceptualization of formative assessment. A randomly selected group was selected and they were trained in formative assessment practices in classroom situations. Firstly, the participants introduced to the concept of formative assessment, its uses and the basic philosophy of it which was followed by hands-on practices in classroom assessment. After this intervention, the pretest scores were compared to their scores of posttest which reflected that the participants have made a significant improvement. Further, the effect of formative assessment practices on students' academic achievement was measured which showed that formative assessment practices have positive influences on students achievement.

William Black (1998) discussed the importance of formative assessment and its proper use in classroom learning and pointed feedback as the most important aspects which support students' achievement. This study was further signified by the work of Stiggins (2004) and Popham (2011) where assessment and its classroom used for the improvement of learning were scholarly proved. Stiggins emphasis on the clarification of teacher's beliefs regarding assessment and presented the correct belief, where he identified four mistaken beliefs of teachers about assessment and its corrected version were presented. Similarly, Popham through his work on A Teacher Confession discussed the mistakes he committed during the initial phase of teaching. He accepted that because of low assessment knowledge and skills there were flows in his instructional decisions for which he confesses. Such studies emphasize the importance of teachers' assessment literacy which aimed to avoid the confusions and worries of teachers in classroom assessment.

Another study conducted by Popham (2009) revealed that assessment literacy is the required skills and knowledge of teachers which enable them to effectively implement their instructional plan in the class. From a definition perspective, assessment literacy was defined as the knowledge and skills deemed necessary for teachers and administrator to conduct educational decisions. Similarly, on the question that assessment is a fashion in the teaching profession or a necessity of teachers? The research replied that it is the most important element of teaching profession which enables the teacher to plan and even re-plan the instruction. Furthermore, it enables the teacher to help out the students to improve their learning, design the curriculum effectively, implement the curriculum at the classroom level and bring continues developments in teaching-learning process. 
A $\mathrm{PhD}$ dissertation was conducted by (Davidheiser, 2013) on assessment literacy of teachers in United States of America at the school level. The study identified and used the assessment literacy standards of AFT and NCME for measuring the assessment literacy of teachers. There were seven standards for assessment literacy of teachers; an assessment literacy scale was designed to measure their assessment literacy. The results of the study indicated the majority of the respondents need training in assessment literacy. These standards were designed by AFT and NCME for measuring teacher competence in classroom assessment of students' performances. Furthermore, these standards are used for issuance of a license to teachers, certification, and accreditation purposes of teacher education departments. Another similar study was conducted by Mohamed, Kamis, and Ali (2017) on investigating assessment literacy level of teachers in the subject of home economics in Malaysia. The results of the study showed that these teachers need continues professional development training in assessment literacy as their assessment literacy was of moderate level. In nutshell there is a significant relationship of assessment literacy of teachers with the academic achievement of their students.

\section{Research Methodology}

\section{Research Design}

The study in hand was designed keeping in view the parameters of quantitative research design. The study was descriptive correlational and data were collected through assessment literacy test from the respondents of the study. For this purpose, a survey was conducted.

\section{Population}

The population of the study was comprised of all two hundred and ninety teacher educators of Government College for Elementary Teachers (GCETs) of Punjab working under the Directorate of Staff Development (DSD) and one hundred and twenty teacher educators of Regional Institutes of Teacher Education (RITE) of Khyber Pakhtunkhwa working under the Directorate of Curriculum and Teacher Education (DCTE) and provincial Ministry of Education. The overall population was comprised of (410) teacher educators from the selected institutions. Furthermore, there were 817 prospective teachers in GCETs and RITE in the session of Fall, 2016 studying in semester four. The above mentioned population was 
selected because the researchers intended to analyze the assessment literacy level of teacher educators and to measure that if there is any relationship with the academic achievements of the prospective teachers. Furthermore, all the teacher educators included in the population were involved in the preparation of prospective teachers.

\section{Sampling and Sample Group}

Through random sampling techniques, a sample group from teacher educators of both provincial institutions and prospective teacher were selected. Through proportionate random sampling techniques fifty per cent teacher educators and twenty-five per cent prospective teachers were taken in the sample group. The total sample group of the study was comprised of 205 teacher educators and 205 prospective teachers from the selected institutions of the study. All the thirty-three teacher educators who were the part of a pilot study for the assessment literacy test were not the part of the sample group.

\section{Research Instrument}

An assessment literacy test designed and used by Stiggins and Chappuis (2014) of the United States of America in the State of Oregon was modified with the permission of the authors and was used for data collection from teacher educators of GCETs and RITE.

The test was divided into seven components which were designed keeping in view the assessment literacy standards developed by AFT and NCME. These seven components include:

i. Purposes of formative assessment

ii. Clear learning outcomes

iii. Designing and selecting appropriate assessment tools

iv. Assessing achievement goals

v. The use of MCQs, short answers, observations and question answering in the teaching process

vi. Communicating the results of the assessment to the stakeholders

vii. Feedback, grading, and nature of students' performances

There were seven items on the first component, twelve on the second, eight on the third, four on the fourth, twelve on the fifth, eight on the sixth and eleven on the seventh component of the test. Overall there were sixtytwo items in the test which was covering all the key variables and constructs of assessment literacy. 


\section{Reliability and Validity}

The test was first pilot tested on thirty-three teachers from the population of the study which is $8 \%$ of the selected population and $16 \%$ of the sample group selected for this study which is sufficient for pilot testing of the research instrument (Julious, 2005). The reliability coefficient was calculated which was $\mathrm{KR}=.771$ which was acceptable according to Griffee (2012) who was of the opinion that when the reliability coefficient is above .70 it is acceptable for the use of data collection in social sciences. Furthermore, the reliability coefficient of all seven components of assessment literacy test was also measured which was an acceptable range as recommended by Griffee (2012).

To estimate the content validity of the test, the test was administered to five experts in the field assessment and measurement. All the recommended changes were carried out in the test. After these considerations, the test was administered to the respondents of the study with a consent form containing the basic information regarding the study. Most of the data were collected by the researcher personally through personal visits; furthermore, Google form option was also used for data collection on which only five respondents replied.

To collect data from prospective teachers on their academic achievement their third-semester marks were used which was collected from the concerned departments' offices.

\section{Data Analysis Instrument}

Statistical Package for Social Sciences (SPSS) version 20 was used for data analysis purposes. The collected data were analyzed through mean scores and standard deviations. These descriptive statistics were used to analyze the assessment literacy level of teacher educators while the scores of student teachers were represented through percentage. Furthermore, to measure the correlation of assessment literacy and prospective teachers' academic achievement Pearson correlation and linear regression were applied.

Furthermore, the data normality was measured through the skewness and kurtosis z values (range from -1.96 to + 1.96) and the Shapiro-Wilk test $\mathrm{p}$ value (above 0.05). Based on the results from SPSS output the Skewness and Kurtosis z values were- 1.626 and .913 which are in the 
prescribed ranges of normality. Similarly, the Shapiro-p value .280 which is above than .05 . This reflected that the data is normally distributed.

\section{Results and Interpretation}

Demographic information

The demographic variables of the test include gender-wise classification of the respondents, their academic and professional qualifications. Furthermore, the in-service training if any attended in the assessment was also included in this section. There were one hundred and thirty-one male and seventy-four female respondents. Furthermore, there were one hundred and sixty-four Masters, thirty-six, M.Phil and only five $\mathrm{PhD}$ respondents from academic qualification perspectives. However, there were eighteen respondents who have done their B.Ed, one hundred and fifty-three respondents have done B. Ed and M.Ed while thirty-four respondents have done other professional qualification.

Similarly, majority one hundred and sixty-seven haven't attended any in-service training on assessment, twenty-four respondents were of the opinion that they have done 1 to 4 weeks training in assessment while only fourteen respondents have attended more than four weeks in-service training in assessment.

Table 1

Teacher Educators Assessment Literacy (Component-wise Results)

\begin{tabular}{|c|c|c|c|c|c|}
\hline S\# & $\begin{array}{l}\text { Assessment } \\
\text { literacy component }\end{array}$ & Minimum & Maximum & Mean & Std D \\
\hline 1 & $\begin{array}{l}\text { Purposes of } \\
\text { formative } \\
\text { assessment }\end{array}$ & 1.00 & 7.00 & 4.3707 & .83966 \\
\hline 2 & $\begin{array}{l}\text { Clear learning } \\
\text { outcomes }\end{array}$ & 3.00 & 12.00 & 8.5366 & 2.07574 \\
\hline 3 & $\begin{array}{l}\text { Designing and } \\
\text { selecting } \\
\text { appropriate } \\
\text { assessment tools }\end{array}$ & 2.00 & 13.00 & 4.8634 & 1.22909 \\
\hline 4 & $\begin{array}{l}\text { Assessing } \\
\text { achievement goals }\end{array}$ & 1.00 & 4.00 & 2.4049 & 1.16188 \\
\hline
\end{tabular}




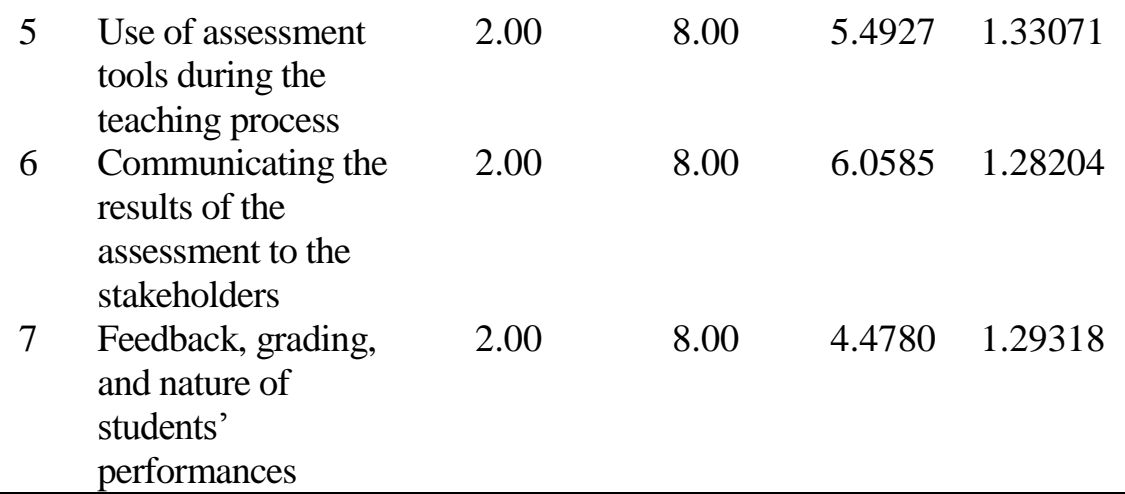

The mean score on the first component of assessment literacy on the "purpose of formative assessment practices" of teacher educators showed their moderate level understanding. It revealed that teacher educators know the purposes of formative assessment and they have the knowledge and skills of formulating formative assessment objectives.

Similarly, the mean score on the second component of assessment literacy "clear learning outcomes" showed that teacher educators have above than average level assessment literacy. It is reflected in the results that teacher educators can design clear learning outcomes for students' assessment at the classroom level and they include students in designing learning outcomes.

On the contrary, the mean score of third component of assessment literacy "designing and selecting assessment tools" showed that the teacher educators have low literacy in designing and selecting assessment tools. The maximum score was 13.00 while the obtained score of teacher educators were 4.8634 which reflected that teacher educators have a low understanding of designing assessment tools for measuring students learning outcomes. Furthermore, they have a low understanding even on the selection of already developed assessment tools for students' assessment.

Furthermore, the mean score of teacher educators on the fourth component of assessment literacy test show that teacher educators have average level assessment literacy on assessing achievement goals of instruction at the classroom level. Based on the results it was concluded that the majority of teacher educators designed achievement goals in an appropriate manner and they know how to assess the achievement goals of the students. 
Like-wise, the means scores of teacher educators on the fifth component of assessment literacy test show that majority of teacher educators can use MCQs, short answers, classroom discussion, and question-answer sessions for formative assessment of students' learning. Teacher educators have average level assessment literacy in the use of assessment tools in classroom assessment practices.

Similarly, the above mean scores of teacher educators reflected that majority of teacher educators have above than average level assessment literacy on communicating students' assessment results to the stakeholders in a suitable manner. The mean score of teacher educators is 6.0585 and the maximum score is 8.00 which showed that teacher educators do communicate students' assessment results follow appropriate mechanisms, which is they communicate results to their parents in percentages, and in norm reference approaches.

Furthermore, the mean score of teacher educators reflected that majority of them have average level assessment literacy on the seventh component of assessment literacy. These results reflected that teachers do follow feedback practices, they grade students' performances and they understand the nature of students' assessment scores. Furthermore, teacher educators do follow multiple methods of grading and they understand the nature of students' performances and effective approaches to feedback to students.

Table 2

Overall Assessment Literacy of Teacher Educators

\begin{tabular}{|c|c|c|c|c|c|}
\hline & $\begin{array}{l}\text { Assessment } \\
\text { literacy }\end{array}$ & Minimum & Maximum & Mean & $\mathrm{SD}$ \\
\hline 8 & $\begin{array}{l}\text { Assessment } \\
\text { literacy of teacher } \\
\text { educators }\end{array}$ & 24.00 & 49.00 & 36.2049 & 4.73172 \\
\hline
\end{tabular}

The mean score of the above table showed teacher educators assessment literacy on assessment literacy test. The obtained mean score was 36.2049 and the maximum score is 49.00 which showed that the majority of teacher educators have above than average level assessment literacy. 
Table 3

Prospective Teachers' Academic Achievement

\begin{tabular}{lcccc}
\hline Marks ranges & N & Percentage & Mean & SD \\
\hline 205 to 300 & 31 & 15 & & \\
301 to 360 & 65 & 32 & 355.8488 & 53.76275 \\
361 and 480 & 105 & 51 & & \\
481 and above & 04 & .66 & & \\
\hline
\end{tabular}

The table reflected the academic achievement of prospective teachers. The marks ranges of students show that the majority of student teachers performed above the average. There were 31 student teachers who have obtained marks between 205 to 300, 65 student teachers obtained between 301 to 360 and majority one hundred and five student teachers obtained between 361 to 480 marks. While only 4 students obtained more than 480 marks among 205 students. All these showed that the majority of student teachers performed at above average level in their third-semester examination.

Table 4

Co-relation Among Components of Assessment Literacy and Students' Academic Achievement

\begin{tabular}{llllll}
\hline S\# & $\begin{array}{l}\text { Assessment literacy } \\
\text { component }\end{array}$ & Mean & SD & $r$ & Sig \\
\hline 1 & $\begin{array}{l}\text { Purposes of formative } \\
\text { assessment }\end{array}$ & 4.3707 & .83966 & .388 & .000 \\
2 & $\begin{array}{l}\text { Clear learning outcomes } \\
\text { Designing and selecting } \\
\text { appropriate assessment }\end{array}$ & 8.5366 & 2.07574 & .448 & .000 \\
& & & .22909 & .046 & .513 \\
4 & $\begin{array}{l}\text { tools } \\
\text { Assessing achievement } \\
\text { goals }\end{array}$ & 2.4049 & 1.16188 & .679 & .000 \\
& $\begin{array}{l}\text { Use of assessment tools } \\
\text { during the teaching } \\
\text { process }\end{array}$ & 5.4927 & 1.33071 & .126 & .071 \\
6 & $\begin{array}{l}\text { Communicating the } \\
\text { results of the assessment } \\
\text { to the stakeholders }\end{array}$ & 6.0585 & 1.28204 &. .326 & .000 \\
& & & & \\
\end{tabular}



$\begin{array}{llllll}7 & \text { Feedback, grading, and } & 4.4780 & 1.29318 & .211 & .002\end{array}$ nature of students' performances

The Pearson $\mathrm{r}$ values $(.388, .448, .679, .326$ and. 211$)$ of the purposes of formative assessment, designing of learning outcomes, assessing achievement goals of students, communicating results to relevant stakeholders and grading students' performances along with feedback with the academic achievement of students have significant relationships. All these $r$ values are significant as the significant values were less than .05 . These results revealed that the understanding of these assessment literacy components contribute positively to the academic achievement and learning of students.

On the contrary, the Pearson $r$ values .126 and .046 which were not significant as the significant values are higher than .05 reflected that the designing and selection of appropriate assessment tools and their usage during the teaching process have no significant relationship with the academic achievement of students. These results also revealed that teacher educators have low understanding on these two components which didn't contribute positively to students' academic achievement.

Table 5

Relationship Between Teacher Educators' Assessment Literacy and Their Students' Academic Achievement

\begin{tabular}{|c|c|c|c|c|c|}
\hline Variables & $\mathrm{r}$ & $\begin{array}{c}\mathrm{R} \\
\text { Square }\end{array}$ & $\begin{array}{l}\text { Adjusted } \\
\text { R square }\end{array}$ & S.E & Sig \\
\hline $\begin{array}{l}\text { Teacher educators' } \\
\text { assessment literacy } \\
\text { Student teachers' academic } \\
\text { achievement }\end{array}$ & .633 & .391 & .379 & 3.451 & .000 \\
\hline
\end{tabular}

The Pearson $r$ value .633 showed significant relationship between the assessment literacy levels of teacher educators with the academic achievement of prospective teachers. Further the R square value .391 showed that assessment literacy of teacher explains 39\% students' academic achievement. Furthermore, it also reflected that when teacher educators have high assessment literacy it will positively contribute to the academic achievement of their students 


\section{Conclusions}

Keeping in the results of the study following conclusions were drawn;

The results revealed that majority of teacher educators have no inservice training in assessment which is one of the reasons for their low assessment literacy. Teaching profession is a growing profession and every day new developments take place but the absence of in-service training in assessment remains the teacher educators unaware of these developments.

It was concluded that majority of teacher educators have average level assessment literacy on the purposes of formative assessment, feedback, and nature of students' performances and on the use of assessment tools during the instruction process. It was important to mention that most teacher educators were found very competent in giving feedback to students on their work.

Furthermore, it was concluded that most of the teacher educators have above average level assessment literacy on clearing outcomes and achievement goals which show their competence on design clear learning outcomes and they were involving students in designing achievement goals for students.

On the other hand teacher educators were found reluctant in the designing of assessment tools and this may be the weak area which needs proper consideration.

From the results of students' academic achievement, it was concluded that majority of prospective teachers have above average level academic achievement in their third-semester score.

Except of designing and selecting appropriate assessment tools and the use of assessment tools during teaching learning process all the components of assessment literacy have significant relationship with the academic achievement of students.

From the results of Pearson $r$ and linear regression a significant correlation was recorded between teacher educators' assessment literacy and prospective teachers' academic achievement. Furthermore, it was reflected from the results that when teacher educator educators have higher assessment literacy it will positively contribute into their students' academic achievement.

\section{Discussion}

The scarcity of in-service trainings for teachers in different aspects of teaching in general and assessment in particular have negatively affected the quality of teachers' teaching. The results of this study revealed the majority of teacher educators haven't attended any in-service training in assessment. According to Darling-Hammond, and Lieberman (2013) the quality of teachers may be developed through in-service training and refreshing courses 
along with other measures in this regard. Further, in developed countries like United States of America, Canada, Australia, New Zealand and United Kingdom there are separate bureaus and councils for assessment knowledge and standards (Gotch, \& French, 2014) but Pakistan has no such center for the excellence of assessment knowledge in the country.

From the perspective of assessment literacy, teacher educators understand the purposes of formative assessment practices which increase the probability of frequently use of formative assessment practices. These results are in accordance with the study of Black and Wiliam (2010) where formative assessment practices were identified beneficial for students' academic achievement. Similarly, Davidheiser (2013) concluded that the understanding of classroom assessment practices empowers teachers to adopt alternative assessment measure which reduces students' anxiety level and positively contribute to students' achievement.

Likewise, teacher educators were found good in designing learning outcomes and assessing achievement goals which are important for the application of assessment theory into classroom practical situation. As reflected by the study of La Paro, Pianta, and Stuhlman (2004) who opined that classroom learning outcomes and classroom assessment need to be align with each other, this alignment may help the learners in preparation and the teachers in the delivery of instruction. Further the results also showed that teacher educators were unable to design assessment tools in accordance with the principles of assessment which may negatively affects the quality of assessment results. As Popham (2011) revealed that ignorance or incompetence in assessment yields poor students' results, for which all the responsibilities lies on the shoulders of teachers.

Similarly, the average level of teacher educators' understanding in the use of assessment tools like MCQs, one minute tests, classroom observations and questionings revealed the need of assessment trainings and orientations of teacher educator. These results are supported by the study of Brown (2005) who was of the view that teachers mostly use questioning techniques for assessing students' understanding in classrooms. Furthermore, in the book of Gardner, and Gardner (2012) multiple assessment tools for students' classroom understanding were recommended to teachers.

Like, the understanding of learning outcomes and use of assessment tools teacher educators were found good in communicating assessment results to stakeholders. The communication of results through notice board, individual results through detail mark certificates and returning scripts to students only, but the most important stakeholder (parents) is always ignored. Andersson, and Palm (2017) viewed that the communication of assessment results are important for taking relevant inferences and decisions. Furthermore, on students' feedback, grading and 
nature of assessment data majority of the teachers were found confused as they were unable to convey constructive feedback to students. La Paro, Pianta, and Stuhlman (2004) have identified the benefits of effective feedback and concluded that without effective feedback students learning abilities cannot be developed. Furthermore, Stevens and Levi (2013) revealed the alternative approaches in assessment tools, feedback and students' performances grading. All the prominent tools and approaches were properly explained in the literature but the results of their study were similar to the current study.

Overall, the assessment literacy of teacher educators in Pakistan was moderate level. The results of Davidheiser (2013), Mohamed, Kamis, and Ali (2017) and Popham (2011: 2013) are similar to the results of current study where majority of the respondents have low and average level assessment literacy. Similarly, the academic achievement of prospective teachers was found of average level which may be the result of the assessment literacy level of teacher educators. The results further showed assessment literacy explains 39\% academic achievement of prospective teachers which reflects its importance.

\section{Recommendations}

i. Keeping in view the results, conclusions and discussions of the study following recommendations were made;

ii. A National Assessment Wing (NAW) may be formulated under the umbrella of National Curriculum Wing (NCW) which may plan for assessment studies, in-service training and workshops. Furthermore, this wing must design assessment standards for teachers.

iii. A series of workshops on assessment skills and knowledge may be arranged for GCETs and RITE teacher educators with the consultation of Learning and Innovation Division (LID) of Higher Education Commission to enhance the knowledge and skills of teacher educators.

iv. Along with training and workshops on assessment, it is recommended that teacher education institutions may provide internet access that they could use online resources to enhancing their assessment literacy and improving their professional competencies.

v. Teacher educators are recommended that they work for their own professional development following every available opportunity in their local settings. They could also benefit from the experience of the teacher education department of universities.

vi. For future research, it is recommended that an experimental study may be designed on the instructional practices of assessment and evaluation in teacher education. 


\section{References}

Andersson, C., \& Palm, T. (2017). The impact of formative assessment on student achievement: a study of the effects of changes to classroom practice after a comprehensive professional development programme. Learning and Instruction, 49, 92-102.

Black, P., \& Wiliam, D. (1998). Assessment and classroom learning. Assessment in Education: principles, policy \& practice, 5(1), 7-74.

Black, P., \& Wiliam, D. (2010). Inside the black box: Raising standards through classroom assessment. Phi Delta Kappan, 92(1), 81-90.

Black, P., Harrison, C., Lee, C., Marshall, B., \& Wiliam, D. (2004). Working inside the black box: Assessment for learning in the classroom. Phi delta kappan, 86(1), 8-21.

Boud, D., Cohen, R., \& Sampson, J. (Eds.). (2014). Peer learning in higher education: Learning from and with each other. Routledge.

Brown, S. (2005). Assessment for learning. Learning and teaching in higher education, (1), 81-89.

Darling-Hammond, L., \& Lieberman, A. (2013). Teacher education around the world: What can we learn from international practice? In Teacher education around the world (pp. 165-183). Routledge.

Davidheiser, S. A. (2013). Identifying areas for high school teacher development: A study of assessment literacy in the Central Bucks School District (Doctoral dissertation, Drexel University).

Gardner, J. N., \& Gardner, J. (Eds.). (2012). Assessment and learning. Sage.

Gotch, C. M., \& French, B. F. (2014). A systematic review of assessment literacy measures. Educational Measurement: Issues and Practice, 33(2), 14-18.

Griffee, D. T. (2012). An introduction to second language research methods: Design and data. TESL-EJ Publications, Berkeley.

Julious, S. A. (2005). Sample size of 12 per group rule of thumb for a pilot study. Pharmaceutical Statistics: The Journal of Applied Statistics in the Pharmaceutical Industry, 4(4), 287-291.

La Paro, K. M., Pianta, R. C., \& Stuhlman, M. (2004). The classroom assessment scoring system: Findings from the prekindergarten year. The Elementary School Journal, 104(5), 409-426. 
Lorna M.(Lorna Maxine) Earl, \& Manitoba. (2006). Rethinking classroom assessment with purpose in mind: Assessment for learning, assessment as learning, assessment of learning. Manitoba Education, Citizenship and Youth.

Mohamed, S., Kamis, A., \& Ali, N. (2017). Gauging the assessment literacy of Malaysia's home economics teachers: An empirical study. GeografiaMalaysian Journal of Society and Space, 12(3), 130-138.

Nicol, D. J., \& Macfarlane-Dick, D. (2006). Formative assessment and self-regulated learning: A model and seven principles of good feedback practice. Studies in higher education, 31(2), 199-218.

Popham, W. J. (2009). Assessment literacy for teachers: Faddish or fundamental?. Theory into practice, 48(1), 4-11.

Popham, W. J. (2011). Assessment literacy overlooked: A teacher educator's confession. The Teacher Educator, 46(4), 265-273.

Scott, T. M., Alter, P. J., \& McQuillan, K. (2010). Functional behavior assessment in classroom settings: Scaling down to scale up. Intervention in School and Clinic, 46(2), 87-94.

Stevens, D. D., \& Levi, A. J. (2013). Introduction to rubrics: An assessment tool to save grading time, convey effective feedback, and promote student learning. Stylus Publishing, LLC.

Stiggins, R. (2004). Improve assessment literacy outside of schools too. Phi Delta Kappan, 96(2), 67-72.

Stiggins', R., \& Chappuis, J. (2014). Stiggins/chappuis test of Classroom Assessment Literacy and Answer Key. Oregon, United States of America: Oregon Statewide Assessment Literacy Project Adaptation, a Collaborative effort of COSA, OEA, Oregon DOE and ATI.

Citation of this Article:

Hussain, S., Kayani, M. M., \& Akhtar, Z. (2018). A correlational study on teacher educators' assessment literacy and their students' academic achievement. Pakistan Journal of Education, 35 (3), 59-76. 